\title{
Identification of Physical Characteristics and The Change of Mangrove Region in Coastal Southern Part of Padang City West Sumatra-Indonesia
}

\author{
* Triyatno ${ }^{1}$, Febriandi ${ }^{1}$, Aprizon Putra ${ }^{1}$, and Eni Kamal ${ }^{2}$ \\ ${ }^{1}$ Department of Geography, Universitas Negeri Padang, Indonesia \\ ${ }^{2}$ Faculty of Fisheries and Marine Science, Bung Hatta University, Indonesia \\ E-mail : triyatno@ fis.unp.ac.id
}

*Corresponding Author, Received: March 10, 2019, Revised: April 10, 2019, Accepted: May 10, 2019

\begin{abstract}
The research about the identification of mangrove physical condition and the change of mangrove area has aims are knowing of mangrove physical condition and the change of mangrove area in the coastal region southern part of Padang city. The method used in this research is the field survey and multi-temporal satellite imagery analysis in 2001 and 2018 year. Based on the field survey at the date of August 18, 2017 generally the mangrove that found in research location i.e Rhizophora apiculata, Rhizophora mucronata, Sonneratia alba, and Nypa. The spatial distribution of the mangrove ecosystem is dependent on the ecological conditions of the area as reflected by the types of mangrove vegetation that grows and develops in the research location. A decrease in mangrove area that occurred between of 2001 to the 2017 years i.e in the coastal region of Bungus bay i.e 5.54 ha, where the decrease in mangrove area occurred because some mangrove plants were cut down and made the settlement land, while in the region of Sungai Pisang bay happen to increase in mangrove area i.e $36.12 \mathrm{ha}$, where the increase in mangrove area occurred because of the region obstructed by big waves of the sea (protected small the islands).
\end{abstract}

Keywords: Mangrove, Satellite Imagery, Coastal Southern, Padang City

\section{Introduction}

Mangrove is an ecosystem found in wet areas that are still affected by tidal sea water, ordinary mangrove vegetation can grow well in areas that still have a certain salinity. Commonly grown mangrove vegetation have their own pattern and zoning following the distribution of mud, sand, peat, waves, and tidal effects of seawater in an area so that mangrove vegetation grows and developers have their own propagation pattern that has its own characteristics that reflect physical characteristics of a region (Rochmady, 2015; Nicolás et al, 2017; Triyatno el al, 2018; Hermon et al, 2018; Hermon, 2019). Noor et al (2012); Gruetersa et al (2014); Hermon et al (2017); Proisy et al (2017) adds the mangrove vegetation has good adaptability to extreme environmental conditions such as high salinity, constantly inundated areas, strong tides, waves, and strong wind from of the sea. With such extreme environmental conditions, mangrove vegetation adapt to develop mechanisms that can remove salt from the leaf, and others develop breathing roots to obtain oxygen.

Mangrove ecosystem has a very important role for life in the coastal area. This mangrove plants a role in protecting coastal areas and maintaining the ecosystem of flora and fauna in the surrounding area, mangrove also serves to preserve biodiversity Castillo et al, 2017; Febriandi, 2017. In addition, mangrove also has economic potential that can be obtained from three main sources of forest products, fisheries, and ecotourism (Putra et al, 2018). Mangrove forests are often referred to as mangrove forests due to mangrove 
vegetation or the types of Rhizophoraceae tribes that often dominate in the coastal region. The types of Rhizophoraceae tribes include Rhizopora mucronata, Rhizopora apiculata, and Rhizopora stylosa. Several other types are found i.e Bruguiera gymnorrhiza (Putra et al, 2015). Generally, the region of mangroves can be found throughout the Indonesian archipelago. The largest mangrove region is located in Papua island around 1,350,600 ha (38\%), Kalimantan island 978,200 ha (28\%), and Sumatera island 673,300 ha (19\%) (Dwi, 2005; Noor et al, 2012; Triyatno et al, 2016).

The mangrove vegetation in Indonesia consists of 47 species of trees, 5 species of bushes, 9 species of herbs and grasses, 29 species of epiphytes, 2 species of parasites, and several species of algae and bryophyta (Noor et al, 2012; Putra et al, 2015). Dwi (2005); Kolinug et al (2014); Triyatno (2017) explains the mangrove forest formation consists of four main genera, i.e Avicennia, Sonneratia, Rhizophora, and Bruguiera. To identify mangrove vegetation can be done using satellite imagery of Landsat primarily to see changes of mangrove vegetation, mangrove vegetation changes can be analyzed using Normal Differential Vegetation Index (NDVI) on satellite imagery (Putra et al, 2015; Alatorre et al, 2016; Wilfrid et al, 2016; Jinyan et al, 2017). Where city that has mangrove vegetation in the administrative area of West Sumatera province in the Padang City.

The existence of mangrove vegetation in the coastal region of Padang City is mostly found in the coastal southern part, this is caused by the characteristics of different areas between the north and south of Padang City. Generally, the northern part of Padang City has the material of the region in the form of sand that mostly comes from the upper land, while in the southern part of Padang City has the material of the region composed of sand, coral reefs and mud. Along with the increasing number of total population and the need for land increased cause it to occur land conversion, such as agricultural land into settlements and mangrove forests into settlements, therefore need to be analyzed changes in mangrove area and mangrove plant physical characteristics. This research aims to analyze the mangrove types (physical characteristics) and analyze the changes in mangrove area in the southern part of Padang City.

\section{Method}

The method used to analyze the change of mangrove area in the coastal region of southern part Padang City i.e in 2 bay regions (Bungus and Sungai Pisang) were done by analyzing Landsat TM imagery 2001 and Landsat OLI 2017. While to analyze the characteristic of the region, determined based on mangrove types analyzed based on reflection value of satellite imagery Landsat Darmadi et al (2016); Alatorre et al (2016); Wilfrid et al (2016); Nicolás et al (2017), and to identify the condition of mangrove vegetation carried out with the combination method between the path method and the line method (square plot) that placed perpendicular to the coastline to land with a width of $10 \mathrm{~m}$ and length depending on field conditions (the distance of the mangrove vegetation on the beach with the mangrove border with land behind the mangrove vegetation) (Hermon, 2016). The analytical techniques used to distinguish mangrove vegetation from other land uses (forests vegetation) i.e with Normal Differential Vegetation Index (NDVI) methods. This NDVI analysis technique is well used to analyze the characteristics of forest structures (Alatorre et al, 2016; Wilfrid et al (2016); Jinyan et al, 2017). NDVI values in satellite imagery can be formulated as follows:

$$
\mathrm{NDVI}=\frac{\mathrm{IR}-\mathrm{R}}{\mathrm{IR}+\mathrm{R}}
$$

NDVI $=$ normal differential vegetation Indexs

IR = infrared spectral band

$\mathrm{R} \quad=$ red spectral band.

\section{Result and Discussion}

\section{Type of Mangrove}

The mangrove types found in the research location are Rhizophora apiculata, Rhizophora mucronata, Sonneratia alba, and Nypa. Distribution of mangrove type shows differences in physical 
characteristics or ecological conditions the place of mangroves grows and develop. For more details can be seen in Table 1 follows:

Table 1. Types of Mangroves and Physical Characteristics

\begin{tabular}{|c|c|c|c|}
\hline \multirow{2}{*}{$\begin{array}{c}\text { Mangrove } \\
\text { Types }\end{array}$} & \multicolumn{2}{|c|}{ Physical characteristics } & \multirow{2}{*}{$\begin{array}{l}\text { Physical Characteristics } \\
\text { (Ecological Condition) }\end{array}$} \\
\hline & Leaf appearance & Flower & \\
\hline $\begin{array}{l}\text { Rhizophora } \\
\text { apiculata }\end{array}$ & $\begin{array}{l}\text { Dark green skin with light green } \\
\text { on the middle and redness at the } \\
\text { bottom. The leaf strap is } 17-35 \\
\text { mm long and the colour is reddish. } \\
\text { Unit \& Layout: simple \& opposite. } \\
\text { Shape: the ellipse narrows. Edge: } \\
\text { tapering. Size: } 7-19 \times 3.5-8 \mathrm{~cm} \text {. }\end{array}$ & $\begin{array}{l}\text { Flower: Bisexual, yellowish flower } \\
\text { head located on the handle }<14 \\
\text { mm. Crown leaves: yellow-white, } \\
\text { no hair, length of } 9-11 \mathrm{~mm} \text {. Fruit: } \\
\text { Roughly rounded fruit elongated to } \\
\text { pear-like, brown, length of } 2-3.5 \\
\text { cm. }\end{array}$ & $\begin{array}{l}\text { Grows on muddy soil, smooth, deep and } \\
\text { inundated during normal tide. Dislikes } \\
\text { harder substrates mixed with sand. The } \\
\text { level of dominance can reach } 90 \% \text { of the } \\
\text { vegetation growing in a location. Loves } \\
\text { tidal waters that have a strong permanent } \\
\text { influence of freshwater input. }\end{array}$ \\
\hline Nypa & $\begin{array}{l}\text { Like the arrangement of coconut } \\
\text { leaf. Length of bunch/leaf } \\
\text { handlebar } 4-9 \mathrm{~m} \text {. There are } 100- \\
120 \text { leaves on each leaf bunch, } \\
\text { glossy green on the upper surface } \\
\text { and powdered at the bottom. } \\
\text { Shape: lanceolate. Edge: tapering. } \\
\text { Size: } 60-130 \times 5-8 \mathrm{~cm} \text {. }\end{array}$ & $\begin{array}{l}\text { Bunches of bisexual flowers grow } \\
\text { from near the top of the stem on the } \\
\text { handle as long as } 1-2 \mathrm{~m} \text {. The } \\
\text { female flowers form a circular head } \\
25-30 \mathrm{~cm} \text { in diameter. Bright } \\
\text { yellow male flowers, located under } \\
\text { the head of the flower. Fruit is } \\
\text { round, brown, stiff and fibrous. } \\
\text { Size head fruit diameter up to } 45 \\
\mathrm{~cm} \text {. Seed diameter of } 4-5 \mathrm{~cm} \text {. }\end{array}$ & $\begin{array}{l}\text { It grows on a smooth substrate, at the top } \\
\text { edge of the waterway. Requires high } \\
\text { annual freshwater input. It is rare outside } \\
\text { the coastal zone. Usually grows on a } \\
\text { grouped stand. It has a strong, dense root } \\
\text { system that is better adapted to changes in } \\
\text { water input, compared to most other } \\
\text { mangrove species. Sticky pollen and } \\
\text { pollination seem to be aided by the } \\
\text { Drosophila fly. }\end{array}$ \\
\hline
\end{tabular}

Source: Noor et al, (2012) and the results of data analysis (2017).

Based on Table 1 above can be seen the distribution of mangrove plants depending on the physical condition or ecological conditions of an area. Generally, mangroves Rhizophora apiculata type can grow and develop well in areas that have a subtle material in the form of mud and flooded during normal tide. Mangrove Rhizophora apiculata type are found in coves, especially in Pandan cove, Kaluang cove, Kabuang cove in the coastal region of Bungus bay, and Sungai Pisang cove and Siboko cove in the coastal region of Sungai Pisang bay. Based on the research Putra et al, (2015); Putra (2017); Hermon et al (2018) in the coastal region of Bungus bay and Sungai Pisang bay, this plant is generally grown on the front of the coves area because this area has the material of the forming of fine mud and always inundated by sea water during tidal water.

The mangrove type of Rhizophora mucronata grows and develop around tidal areas and usually grow along with Rhizophora apiculata mangroves but are usually more tolerant of areas with sandy substrates. Mangrove type of Rhizophora mucronata in the coastal region of southern part Padang city grows and develop on the back of Rhizophora apiculata mangrove type which generally has the sandy material and still gets the effect of sea tides. The mangrove type of Sonneratia alba generally on the back of Rhizophora mucronata with environmental conditions that has a muddy and sandy soil. Based on research [24] mangrove type Sonneratia alba is generally not formed the root of the breath in an environment that has a hard and rough material, while in the environment that has mud materials and a little sandy mangrove species will 
have a root breath, especially if growing and developing in an environment that is always inundated. Nypa is a type of mangrove plant that grows and develops around the environment that has a lot of fresh water, especially around the river (Okpiliya et al, 2013). In the coastal region of southern part Padang City, Nypa plant is grown not so much this is because this plant requires a lot of fresh water so spread just around the area that has a river. This plant is spread in the area of the Bungus river, Timbalun river, and Sungai Pisang river.

\section{The change of mangrove cover}

The change in a mangrove area generally occurs naturally or as a result of human activities that make changes around the mangrove vegetation. To analyze the change of mangrove area is done by interpretation of Landsat imagery of TM 2001 and OLI 2017. Satellite imagery interpretation result showed that in 2001 mangrove vegetation was only found in the middle part of the coastal region of Bungus bay especially around Kabung cove, Kaluang cove, and Pandan cove. For more details can be seen in Table 2 follows:

Table 2. Mangrove Cover Area in 2001.

\begin{tabular}{cccc}
\hline No. & Lands cover & Sub-districts & ha \\
\hline 1 & & & \\
2 & Mangrove vegetation & Bungus Teluk Kabung & 13.68 \\
3 & & & 30.24 \\
\hline
\end{tabular}

Source: Analysis of Landsat TM 2001 satellite imagery.

Based on Table 2 above it can be seen that mangrove vegetation in the 2001 year is only found around pandan cove, kaluang cove, and kabung cove area located in Bungus Teluk Kabung sub-district. This mangrove vegetation is spread only in three places scattered around the bay region with an area larges of 56.52 ha. This indicates that mangrove vegetation can live well in areas that have the material in the form of mud and sand. Generally mud material comes from the upper land that is carried by a river that empties into the estuary area. For more details can be seen in Figure 1 follows:
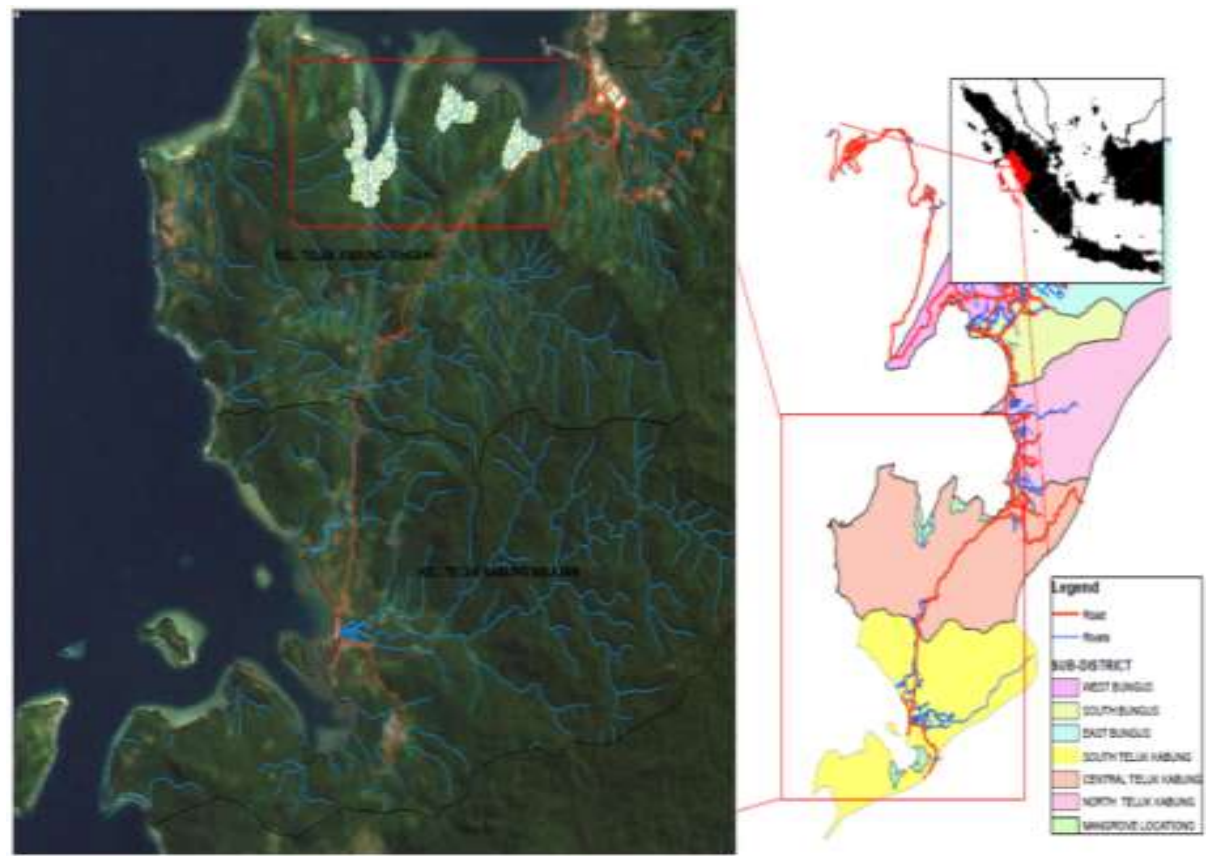

Figure 1. Map of Spatial Distribution of Mangrove Vegetation in The Coastal Region of Bungus bay in 2007 
Based on Figure 1 above can be seen that the mangrove vegetation is only scattered on the bay that has a river that empties into the bay. This small river has a role to transport sediment from the upperlands, especially the material that has a fine size that is in the form of mud and sand. Sand contained in this area can be divided into two parts, i.e sand that comes from land and sand that formed as a result of coral reef debris. The types of mangroves that grow and develop in this area are Rhizophora apiculata, Rhizophora mucronata, Sonneratia alba, and Nypa. The area of mangrove cover in 2017 has increased especially in the Sungai Pisang bay. Increased the mangrove cover area is caused by the local government program to do the conservation or reclamation of the beach, especially using mangrove vegetation. For more detail changes in mangrove cover area in 2017 of year can be seen in Table 3 follows:

Table 4. Mangrove Cover Area in 2017

\begin{tabular}{|c|c|c|c|c|}
\hline No. & Land cover & Sub-districts & Sub-districts & Ha \\
\hline 1 & \multirow{10}{*}{ Mangrove vegetation } & \multirow{10}{*}{ Bungus Teluk Kabung } & & 12.87 \\
\hline 2 & & & The coastal region of Bungus bay & 5.27 \\
\hline 3 & & & & 32.85 \\
\hline & & & Total & 50.99 \\
\hline 4 & & & & 3.24 \\
\hline 5 & & & & 0.54 \\
\hline 6 & & & The coastal regon of Sungai Pisang bay & 1.04 \\
\hline 7 & & & & 17.12 \\
\hline \multirow[t]{2}{*}{8} & & & & 14.18 \\
\hline & & & Total & 36.12 \\
\hline
\end{tabular}

Source: Analysis of Landsat OLI 2017 satellite imagery.

Based on Table 3 above can be seen mangrove cover area changes that mostly increased in the Sungai Pisang bay. The area mangrove cover in the Sungai Pisang bay of 36.12 ha, most of which are spread around the estuary. Generally, estuaries carry material of sand and mud from upper lands that rich in minerals that are needed by plants. In 2017 of year, the area covered by mangrove vegetation in Bungus Teluk Kabung sub-districts experienced a reduction of 6.97 ha, this is due to the change of mangrove cover area into a settlement land and the construction of a power plant in the Sirih bay.
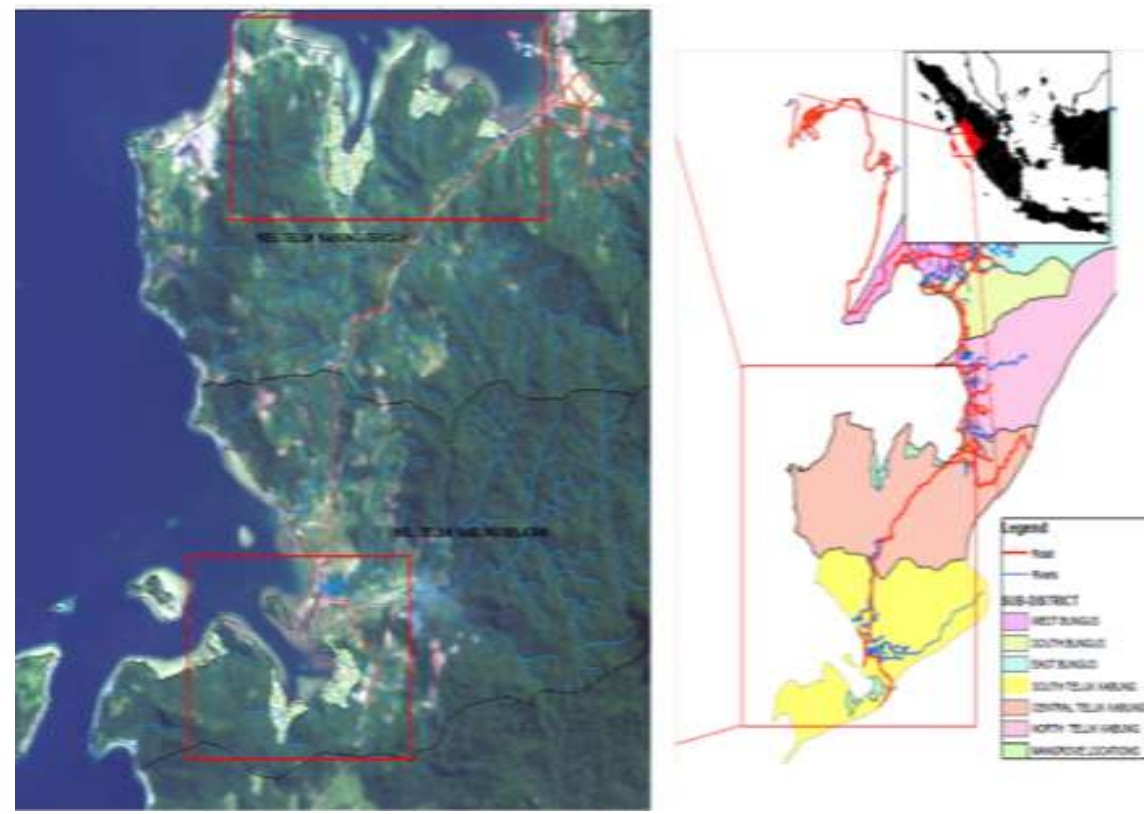

Figure 2. Map of Spatial Distribution of Mangrove Vegetation in The Coastal Southern Part in 2017 
Based on Table 2 and 3, and Figure 1 and 2 above it can be seen that from 2001 to 2017 of the year in the region of Bungus Teluk Kabung sub-district, the mangrove cover area decreased by 5.54 ha or $9.79 \%$ from in 2001. In the southern part of Bungus Teluk Kabung sub-districts experienced an increase of mangrove land cover of 36.12 ha that is around in the Sungai Pisang bay. The types of mangroves found in this area are Rhizophora apiculata, Rhizophora mucronata, Sonneratia alba, and Nypa. The spread of this mangrove types shows different ecological characteristics or ecological environment will affect the growth and development of these mangrove types.

\section{Conclusion}

Based on the results of the interpretation of satellite imagery Landsat that has been done on the coastal southern part of Bungus Teluk Kabung sub-district, the mangrove types found in this area in the form of Rhizophora apiculata, Rhizophora mucronata, Sonneratia alba, and Nypa. The distribution spatial of mangrove type depends on the ecological environment of a region. The changes in the mangrove cover area that occurred in 2001 until the year 2017 showed the dynamics of a very important change in the coastal region of Bungus bay, where the mangrove cover area has decreased by 5.54 ha, while of change in the coastal region of Sungai Pisang bay has increased by 36.12 ha. Based on the results of previous findings, suggestions that can be done to protect mangrove vegetation from extinction can be done as follows; 1) Conducting a deep study of mangrove vegetation and physical characteristics that are indispensable for the growth of mangrove vegetation; 2) Providing counseling to the community so as not to damage the existing mangrove forest; and 3) Issuing local regulations especially for the protection of mangrove vegetation from damage.

\section{References}

Alatorre L C., Sanchez C S., Miramontes-Beltran S., Adams D K., Sanchez E., \& Mario Uc. 2016. Temporal Changes of NDVI for Qualitative Environmental Assessment of Mangroves: Journal of Arid Environments, 98- 109

Alongi, D M. 2002. Present State and Future of The World's Mangrove Forests. Environmental Conservation, 29 (3), 331-349.

Castillo J A A., Apan A A., Maraseni T N., and Salmo S.G. 2017. Soil Greenhouse Gas Fluxes in Tropical Mangrove Forests and in Land Uses on Deforested Mangrove Lands, Catena, 60 - 69.

Darmadi., Wahyudin L M., and Khan A M A. 2016. Community Structure of Mangrove Vegetation Based on Substrate Characteristic in Muara Harmin Cangkring Village, Cantigi Sub-district, Indramayu Regency, West Java., Journal of Fisheries and Marine, 3(3), 347-358.

Dwi S A., Indrowuryatno., Wiryanto., Kusumo W., and Susilowati A. 2005, Mangrove Plant in Central Java Coast: 1 Diversity Type. Journal of biodeversity, 6 (2), 90-94.

Febriandi. 2017. The Estimation of Mangroves Area and Density of Mangroves Changes Use the Remote Sensing Data at Northheast Province of Aceh, Indonesia. Sumatra Journal of Disaster, Geography and Geography Education, 1 (1), 105-110.

Gruetersa, T. Seltmann, H. Schmid, H. Horn, A. Pranchai, A.G. Vovide, R. Peters J. Vogt, F. DahdouhGuebas, U. Berger. 2014. Ecological Modeling the Mangrove Forest dynamics model mesoFONU. Journal Ecological Modeling, 28 - 41.

Hermon, D. 2016. The Strategic Model of Tsunami Based in Coastal Ecotourism Development at Mandeh Regions, West Sumatera, Indonesia. Journal of Environment and Earth Science, 6 (4), 40-45.

Hermon, D., Iskarni, P., Oktorie, O., and Wilis, R. 2017. The Model of Land Cover Change into Settlement Area and Tin Mining and its Affecting Factors in Belitung Island, Indonesia. Journal of Environment and Earth Science. Vo, 7, 32-39.

Hermon D., Ganefri., Putra A., and Oktorie O. 2018. The Model of Mangrove Land Cover Change for the Estimation of Blue Carbon Stock Change in Belitung Island-Indonesia. International Journal of Applied Environmental Sciences, 13(2), 191-202. 
Hermon D., Putra A., and Oktorie O. 2018. Suitability Evaluation of Space Utilization Based on Enviromental Sustainability at The Coastal Area of Bungus Bay in Padang City. International Journal, 14 (41), 193-202.

Hermon, D. 2019. Evaluation of Physical Development of The Coastal Tourism Regions on Tsunami Potentially Zones in Pariaman City-Indonesia. International Journal of GEOMATE, 17 (59), 189-196.

Jinyan T., Wang W., Li X., Huili G., Shi C., Zhong R., and Liu X. 2017. Comparison of UAV and WorldView-2 imagery for mapping leaf area index of mangrove forest. Int $\mathbf{J}$ Appl Earth Obs Geoinformation, 22-31.

Kolinug K H., Langimartina A, Ratag Semuel P, Nurmawan W. 2014. Main Plantation Zone of Mangrove Composers Based on Salinity Level of Sea Water in Teling Village, Tombariri Sub-district, Forest Science Study Program, Department of Agricultural Cultivation, Faculty of Agriculture, Sam Ratulangi University, Manado.

Nicolás Y C., Karen E., Joyce S., and Maier W. 2017. Monitoring Mangrove Forests: Are We Taking Full Advantage of Technology, Earth Obs Geoinformation, 1-14

Noor Y R., Khazali M., and Suryadiputra, I N N. 2012. MANGROVE Introduction Guide in Indonesia, Bogor, Ditjen. PHKA and wetland international Indonesia Programe.

Okpiliya F I., Effiong E B., Eni I., and Eja E. 2013. Mangrove forest ecosystem utilization and depletion: implication for occupational changes In Calabar South, Nigeria. European Journal of Sustainable Development, 2(1), 149-162.

Putra, A., Tanto, T.A., and Ilham. 2015. Aplikasi Citra Satelit Untuk Identifikasi Perubahan Luasan Mangrove di Teluk Bungus Kota Padang. Prosiding Seminar Nasional Sains dan Atmosfer 2015, 33-38.

Putra A. 2017. Evaluasi Kesesuaian Pemanfaatan Ruang Pada Kawasan Pesisir Teluk Bungus Kota Padang. [Tesis]. Pascasarjana Universitas Andalas.

Putra A., Tanto T A., Pranowo W S., Ilham., Damanhuri H., Suasti Y., and Triyatno. 2018. Suitability of Coastal Ecotourism in Padang City-West Sumatera: Case Study of Beach Recreation and Mangrove. J. Segara, 14 (2). 87-94.

Proisy C., Viennois G., Sidik F., Andaya A., Enright J A, Guitetf S, Gusmawati N, Lemonni H., Muthusankarb G., Olagoke A., Prosperi J, Rahmania R., Ricout A., Soulard B., and Suhardjono. 2017. Monitoring of mangrove forests after aquaculture satellite images: A case study from the Perancak estuary, Bali , Indonesia, Marine Pollution Bulletin (2017), 1-11.

Rochmady. 2015. Structure and Composition of Mangrove Types Bonea and Kodiri Villages, Muna Regency, Southeast Sulawesi. the National Maritime and Fisheries Symposium (SIMNAS-KP II) Hasanuddin University, Makassar.

Triyatno, T. 2017. Carbon Stocks Estimate of Padang City West Sumatra Province. Sumatra Journal of Disaster, Geography and Geography Education, 1 (2), 118-123.

Triyatno., Ikhwan, I., and Febriandi. 2018. Strategy for Community Adaptation in Facing Flood Natural Disasters in Pesisir Selatan District, West Sumatra. Sumatra Journal of Disaster, Geography and Geography Education, 2 (2), 16-23.

Wilfrid R., Felle I K., \& Cavanaugh K C. 2016. Spatio-temporal changes of a mangrove-saltmarsh ecotone in the northeastern coast of Florida, USA. journal Global Ecology and Conservation. 245 - 261 